\title{
Future volcanism at Yellowstone caldera: Insights from geochemistry of young volcanic units and monitoring of volcanic unrest
}

\section{Guillaume Girard* and John Stix, Dept. of Earth and Planetary Sciences, Mc Gill University, 3450 University St., Montreal QC H3A $2 A 7$, Canada}

\section{ABSTRACT}

In order to understand possible future scenarios of intracaldera volcanism at Yellowstone, we provide new insights on the generation and eruption of the youngest intracaldera rhyolitic magmas using quartz petrography, geochemistry, and geobarometry. We propose that magma ascent occurred rapidly from the source regions at $8-10 \mathrm{~km}$ to the surface along major regional faults, without storage at shallower depths. These source regions coincide with the upper parts of the present-day imaged magma chamber, while the faults focus much of the present-day caldera unrest. Based on these combined observations, we propose that volcanism has a higher probability to resume in three fault-controlled NNW-trending lineaments, the first coinciding with the western caldera rim, the second lying across the central region of the caldera, and the third extending across the northeastern caldera. The first two lineaments focused recent intracaldera volcanism (174-70 ka), while the latter is the most active in terms of current caldera unrest. Future volcanism could include large-volume lava flows and phreatomagmatic rhyolitic eruptions. The identification of these three regions together with potentially rapid eruptive mechanisms may help to better define future monitoring efforts necessary to improve eruption forecasting in this vast area of volcanic unrest.

\section{INTRODUCTION}

Yellowstone caldera has produced three very large Pleistocene caldera-forming eruptions, also referred to as "super-eruptions" (Sparks et al., 2005): the $2450 \mathrm{~km}^{3}$ Huckleberry Ridge Tuff at $2.06 \mathrm{Ma}$, the $280 \mathrm{~km}^{3}$ Mesa Falls Tuff at $1.29 \mathrm{Ma}$, and the $1000 \mathrm{~km}^{3}$ Lava Creek Tuff at $0.64 \mathrm{Ma}$ (Christiansen, 2001; Lanphere et al., 2002). All Yellowstone eruptions combined equal $\sim 6000 \mathrm{~km}^{3}$ in volume (Christiansen, 2001). Although the caldera does not show signs of an imminent eruption and has not produced Holocene eruptions, the system exhibits numerous signs of unrest, including the highest volcanic degassing rates on Earth (Lowenstern et al., 2006; Christiansen et al., 2007; Lowenstern and Hurwitz, 2008).

Whether Yellowstone is capable of generating future eruptions is a key scientific question. These concerns have spurred recent reappraisals of Yellowstone volcanism, neotectonics, seismicity, ground deformation, and hydrothermal activity, and large geochronological, geochemical, and geophysical datasets have

GSA Today, v. 22, no. 9, doi: 10.1130/GSATG143A.1. been collected in the past decade (e.g., Christiansen et al., 2007; Smith et al., 2009; Girard and Stix, 2010, and references therein). Christiansen et al. (2007) discussed possible future hydrothermal explosions, toxic gas emissions, and volcanic eruptions and their respective associated hazards. They identified hydrothermal explosions and toxic gas emissions as the volcanic hazards most likely to impact humans at Yellowstone. Using geochronology and volumes of volcanic units, they proposed probabilistic assessments of future volcanic eruptions and suggested that a fourth calderaforming eruption was the least likely scenario. Instead, they suggested that intracaldera rhyolitic eruptions and small basaltic or rhyolitic extra-caldera eruptions were more likely, with yearly probabilities of $\sim 5 \times 10^{-5}, 6 \times 10^{-5}$ and $2 \times 10^{-5}$, respectively.

This contribution aims to complement the volcanic eruption hazard model proposed by Christiansen et al. (2007) by examining localities where volcanism is most likely to resume within the caldera. Potential future extra-caldera volcanism is not considered here. We synthesize and expand recent data on rhyolite quartz geochemistry with implications for magma generation, ascent, and eruption forecasting and integrate this information with recent data on the current state of the magma reservoir and geophysical unrest. We identify three NNWtrending intracaldera lineaments that cut through the caldera as foci where volcanism may resume. The western and central lineaments coincide with the eruptive vents of the youngest intracaldera rhyolites (the Central Plateau Member), whereas the eastern lineament lies across the northeastern part of the caldera and is the focus of notable geophysical unrest.

\section{INTRACALDERA VOLCANISM}

\section{Overview and Recent Work}

Since its most recent collapse at $640 \mathrm{ka}$, Yellowstone caldera has experienced a complex history of rhyolitic volcanism. The earliest eruptive products, defined as the Upper Basin Member, are exposed near the two resurgent domes (Fig. 1). Two pyroclastic units and six lava flows were erupted between 516 and ca. $255 \mathrm{ka}$ (Bindeman and Valley, 2001; Christiansen, 2001; Girard and Stix, 2009; Pritchard and Larson, 2012). These rhyolites exhibit extremely depleted and heterogeneous $\delta^{18} \mathrm{O}$ isotopic signatures of $0-4 \%$, suggesting pervasive hydrothermal alteration of their parent magma or protolith (Hildreth et al., 1984; Bindeman and Valley, 2001; Bindeman et al., 2008).

The Central Plateau Member rhyolites, erupted from 174 to $70 \mathrm{ka}$, are the youngest Yellowstone rhyolites (Christiansen, 2001). They

*Now at Dept. of Geosciences, University of Iowa, Iowa City, Iowa 52242-1379, USA; guillaume.girard@mail.mcgill.ca. 

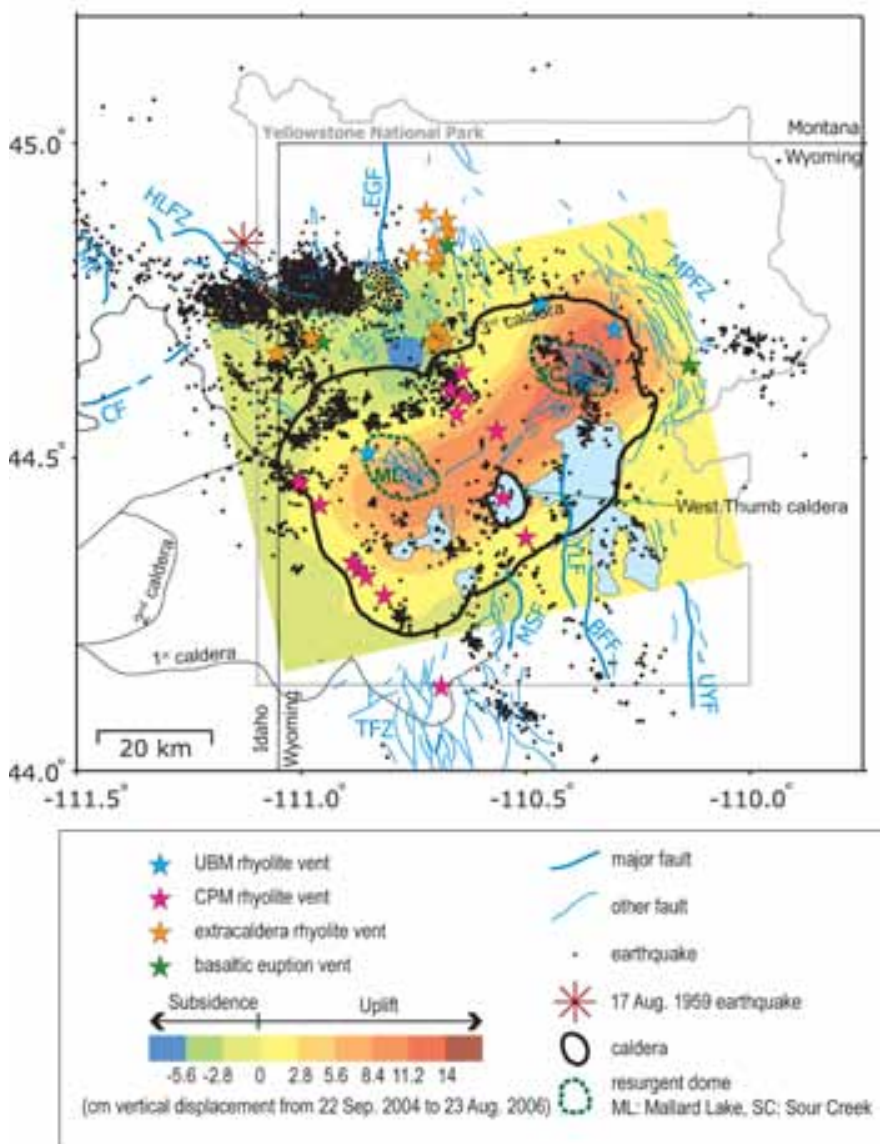

Figure 1. Synthetic compilation map of the Yellowstone region showing mapped eruptive vents active since the last caldera collapse at $640 \mathrm{ka}$ (Christiansen, 2001; Christiansen et al., 2007) (vents for the Gerrit Basalt within the second caldera are omitted on this map and are not considered in this study); earthquakes recorded between 2003 and 2008 (Smith et al., 2009; Taira et al., 2010); faults (Pierce and Morgan, 1992; Farrell et al., 2009); and ground deformation obtained from InSAR measurements during the 20042006 uplift episode (Chang et al., 2007). Map contours modified from Taira et al. (2010). CPM-Central Plateau Member; UBM-Upper Basin Member; BFFBuffalo Fork Fault; CF-Centennial Fault; EGF—East Gallatin Fault; HLFZ— Hebgen Lake Fault Zone; MF-Madison Fault; ML—Mallard Lake resurgent dome; MPFZ-Mirror Plateau Fault Zone; MSF-Mount Sheridan Fault; TFZ-Teton Fault Zone; UYF-Upper Yellowstone Fault; YLF-Yellowstone Lake Fault.

comprise exceptionally large lava flows, with individual volumes of $<1 \mathrm{~km}^{3}$ to $70 \mathrm{~km}^{3}$, and cumulative volumes of $\sim 360-600 \mathrm{~km}^{3}$ (Christiansen et al., 2007). Together with lavas erupted at ca. $255 \mathrm{ka}$, they define a cogenetic series in which the concentrations of most incompatible elements (e.g., Nb, Y, HREE) increase as the lavas become younger, whereas those of compatible elements (e.g., Sr, Ba, $\mathrm{Mg}$, Ti, LREE) decrease, and clinopyroxene and fayalite become more iron-rich (Fig. 2A) (Vazquez et al., 2009; Girard and Stix, 2010). Compared to the Upper Basin Member rhyolites, the Central Plateau Member rhyolites exhibit less depleted and more homogeneous $\delta^{18} \mathrm{O}$ signatures (4-5\%o) (Hildreth et al., 1984; Bindeman and Valley, 2001; Watts et al., 2012). These lavas also have the least radiogenic $\mathrm{Nd}$ isotopic compositions among all Yellowstone rhyolites, approaching the compositions of some Yellowstone basalts. This suggests an increased mantle-derived component compared to older Yellowstone rhyolites (Hildreth et al., 1991; Vazquez et al., 2009).

\section{Quartz Geochemistry, Geobarometry, and Textures and Implications for Central Plateau Magmas}

In order to determine crystallization depths, we investigated a selection of Central Plateau Member lavas for Ti in quartz, which can be used as a geobarometer (Thomas et al., 2010; Huang and Audétat, 2012). Measurements were obtained by laser-ablation inductively coupled plasma-mass spectrometry (LA-ICP-MS) following the protocol of Campbell et al. (2009). In all investigated lavas, a variable fraction $(25 \%-60 \%)$ of quartz crystals were zoned under cathodoluminescence, defining a bright core and a darker rim with a sharp core-rim contact (Fig. 2B). Rims have 17-30 ppm less Ti, on average, relative to the cores (Fig. 2C). The remaining quartz crystals were homogeneous, lacked clear cathodoluminescence and $\mathrm{Ti}$ zoning, and had $\mathrm{Ti}$ concentrations similar to those of the zoned crystal rims (Fig. 2C). The data show a general decrease in the Ti content of quartz from $255 \mathrm{ka}$ to $70 \mathrm{ka}$ in the high Ti cores, lower Ti rims, and unzoned crystals (Fig. 2D). A good correlation also exists between Ti in rims and unzoned crystals and Ti in matrix glass (Fig. 2D), with generally constant partition coefficients of $0.10-0.15$ for Ti between melt and quartz $\left(K_{D_{T i}}\right.$ quartz $\left.=0.10-0.15\right)$. Cores are also typically rounded, suggesting an episode of resorption before the growth of the rims (Fig. 2B). Finally, quartz crystals are typically subhedral (partially rounded) to anhedral (rounded) and commonly show long glass embayments (Figs. 2B and 2E).

We used the recent TitaniQ titanium-in-quartz geobarometer (Thomas et al., 2010; Huang and Audétat, 2012) to estimate depths of formation of the Central Plateau Member quartz crystals (see supplemental Table DR $1^{1}$ ), using magmatic temperatures and $\mathrm{TiO}_{2}$ activity calculated on similar Central Plateau Member units by Vazquez et al. (2009). Despite large uncertainties resulting from the variability in Ti concentrations and imprecision in temperatures and $\mathrm{TiO}_{2}$ activity, the equation of Thomas et al. (2010) gives a pressure range between 5 and $13 \mathrm{kbar}$ throughout the magmatic episode, approximating depths of $20-50 \mathrm{~km}$ in the crust. Using the same temperature and activity estimates, the equation of Huang and Audétat (2012) gives a pressure range of $0.6-5 \mathrm{kbar}$, approximating depths of 2-20 km. Using average values of the Ti contents, $\mathrm{TiO}_{2}$ activity, and temperatures for each lava flow, we obtain pressures of 9-10 kbar and 2-2.5 kbar from these equations, approximating depths of $35-40 \mathrm{~km}$ and $8-10 \mathrm{~km}$, respectively. These calculations reveal large discrepancies between the two experiment-based equations, suggesting that the results should be used with caution. Depths associated with the equation of Thomas et al. (2010) may be unrealistically high, although the continental crust beneath Yellowstone does appear to exceed 40 $\mathrm{km}$ in thickness (Stachnik et al., 2008). By contrast, the depths obtained with the equation of Huang and Audétat (2012) coincide with the depth of the present-day imaged magma reservoir (Husen

${ }^{1}$ Supplemental item 2012246 (Table DR1), is online at www.geosociety.org/pubs/ft2012.htm. You can also request a copy from GSA Today, P.O. Box 9140 , Boulder, CO 80301-9140, USA; gsatoday@geosociety.org. 


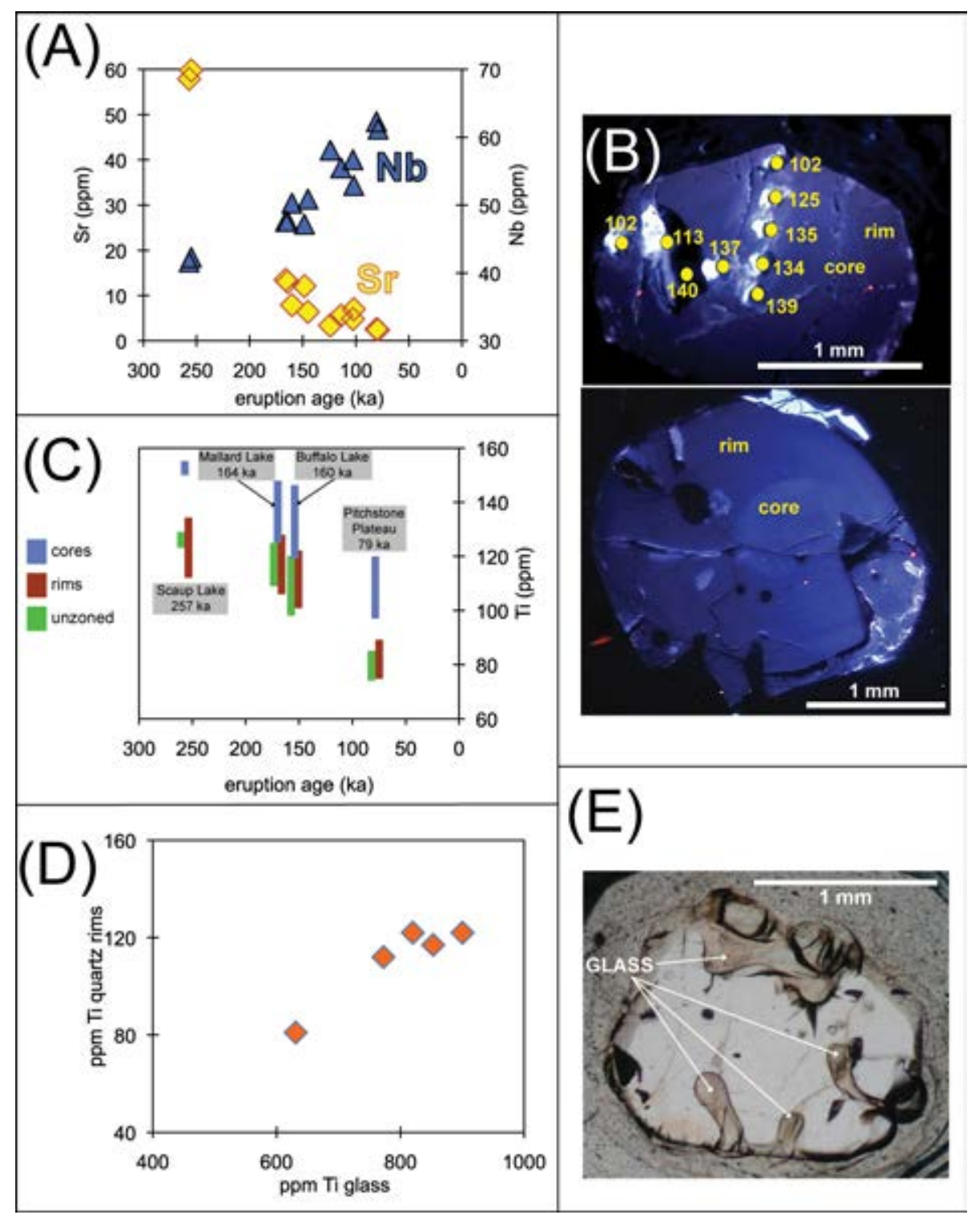

Figure 2. (A) Temporal evolution of $\mathrm{Sr}$ (compatible element) and $\mathrm{Nb}$ (incompatible element) as a function of eruption age in the Central Plateau Member lavas (X-ray fluorescence data on whole rock; Girard and Stix, 2010); ppm-parts per million. (B) Cathodoluminescence photomicrographs of two Central Plateau Member quartz grains (top: Buffalo Lake lava flow, $160 \mathrm{ka}$; bottom: West Yellowstone lava flow, $110 \mathrm{ka}$ ) exhibiting dark rims and bright cores, rounded cores, and subrounded to rounded rims. Yellow circles are $\mathrm{Ti}$ analyses (ppm) by laser-ablation ICP-MS. (C) Ti in Central Plateau Member quartz crystals as a function of eruption age. (D) Average Ti content of quartz rims and unzoned quartz crystals as a function of Ti in glass (electron microprobe analyses; Girard and Stix, 2010). (E) Photomicrograph of glass embayments in a Central Plateau Member quartz crystal (Moose Falls lava flow, $80 \mathrm{ka}$ ).

et al., 2004) (see the "Yellowstone magma reservoir" section), leading us to prefer these values.

Common magmatic processes such as a rapid temperature increase caused, for example, by the injection of a replenishing magma, as well as ascent toward shallower depths, lead to higher solubility of Ti in quartz (Wark and Watson, 2006; Thomas et al., 2010). Should any of these processes have occurred in the Central Plateau magmas to allow for the formation of overgrowths, reverse zoning with higher Ti in rims would be observed, as reported at many silicic magmatic systems elsewhere (e.g., Wark et al., 2007; Wiebe et al., 2007; Shane et al., 2008; Campbell et al., 2009; Matthews et al., 2012). Normal zoning like that observed at Yellowstone appears to be a less common feature in magmatic quartz. The general subhedral (partially rounded) to anhedral (rounded) morphologies of the quartz grains and their abundant glass embayments (Fig. 2E) are most commonly explained by adiabatic decompression during ascent, heating, or a combination of both (Donaldson and Henderson, 1988; Streck, 2008). These features and the lack of reverse zoning lead us to propose that ascent from source region to surface was rapid, with little or no storage at shallower depths. As we discuss in the following section, such rapid ascent may have important implications for our ability to predict volcanic eruptions.

Finally, the higher core Ti content of the zoned crystals may have been inherited from earlier stages of Central Plateau magmatism. In particular, the zoned quartz cores of the $70 \mathrm{ka}$ Pitchstone Plateau lava flow have Ti compositions that closely match those of the unzoned crystals and zoned crystal rims of the $160 \mathrm{ka}$ Buffalo Lake lava flow (Fig. 2C). Hence, the Pitchstone Plateau zoned quartz grains may be antecrysts from the Buffalo Lake episode.

\section{Eruptive Vents and Associated Faults}

A key aspect of the Central Plateau Member rhyolites that is important for assessing future eruption scenarios is the distribution of their eruptive vents along two NNW-trending lineaments aligned with active regional faults. One lineament coincides with the western caldera rim, while the other cuts across the central part of the caldera between the two resurgent domes (Fig. 1). 
These structures traverse the caldera perpendicular to the Yellowstone-Snake River Plain hotspot track and appear to be unrelated to the caldera ring fracture zones (Pierce and Morgan, 1992; Christiansen, 2001) (Fig. 1). Both vent lineaments and, in particular, the central lineament also coincide with regions of high intracaldera tectonic seismicity and hydrothermal activity (Lowenstern and Hurwitz, 2008; Farrell et al., 2009; Smith et al., 2009) (Fig. 1).

Outside the caldera, there is evidence of recent tectonic activity along the faults associated with these lineaments. The Hebgen Lake fault zone, northwest of the western lineament, experienced an $\mathrm{M}_{\mathrm{S}}$ 7.5 earthquake in 1959, the epicenter of which was $25 \mathrm{~km}$ from the caldera rim (Doser, 1985) (Fig. 1). Also in this region, an earthquake swarm in 1985 was interpreted to reflect migration of hydrothermal fluids at depth (Waite and Smith, 2002). Aseismic extension has also been identified in this region (Puskas et al., 2007), as has a lowvelocity zone at $\sim 2 \mathrm{~km}$ depth, interpreted as gas-filled (Husen et al., 2004). South of the western lineament, major Holocene earthquakes with $>1 \mathrm{~m}$ vertical displacement, possibly inherited from melting of the kilometer-thick ice cap that covered Yellowstone during the 3514 ka Pinedale glaciation, have been documented along the Teton fault (Hampel et al., 2007). Leveling measurements along this fault have revealed episodes of uplift and subsidence on the order of $\sim 7$ mm yr-1 (Puskas et al., 2007).

Activity along faults associated with the central lineament (the East Gallatin fault to the north and the Mount Sheridan fault to the south; Fig. 1) is less precisely documented. Nevertheless, these faults exhibit large Pleistocene offsets (Pierce and Morgan, 1992), and the East Gallatin fault hosts active hydrothermal features and volcanic eruptive vents along the Norris-Mammoth Corridor (Christiansen, 2001). Holocene displacements also have been documented along these fault lines in Yellowstone Lake (Morgan et al., 2007).

Considering the volume of the Central Plateau eruptions and the extent of the present-day Yellowstone magma reservoir, which spans much of the caldera subsurface (Husen et al., 2004), it is reasonable to infer that the Central Plateau magma reservoir was not spatially restricted to the areas underlying the vent lineaments. Rather, it might have spanned much of the western and central parts of the caldera subsurface. The faults may have facilitated ascent and eruption of large volumes of poorly phyric rhyolitic magma, preventing their accumulation at shallower levels. The relatively low viscosity of these hot, low-crystallinity magmas and their transit along faults could result in rapid, possibly aseismic (Castro and Dingwell, 2009), ascent with little to no pre-eruptive shallow storage, making forecasting of potential future Central Plateau-type eruptions difficult.

\section{THE YELLOWSTONE MAGMA RESERVOIR}

Seismic tomography and gravity studies beneath Yellowstone caldera have shown the presence of a $-60 \mathrm{mGal}$ gravity anomaly and low P-wave and low $V_{P} / V_{S}$ velocity zone with a density of $\sim 2500 \mathrm{~kg} \mathrm{~m}^{-3}$ at $10-16 \mathrm{~km}$ depth, interpreted as a crystal mush or partial melting zone with 5\%-15\% melt fraction (Husen et al., 2004; DeNosaquo et al., 2009). This magma body lies beneath most of the caldera and has two shallower lobes rising to $6 \mathrm{~km}$ depth beneath each of the two resurgent domes. It may attain $15,000 \mathrm{~km}^{3}$ in volume (Lowenstern et al., 2006). Chu et al. (2010) documented a low-velocity body centered at $5 \mathrm{~km}$ depth beneath the northwestern caldera rim, interpreted as partial melts with $\sim 30 \%$ melt and up to $8 \%$ volatiles. Such melt fractions are usually too low for magma to be eruptible (Marsh, 1981).

The chemical composition of the melts is not well characterized. Owing to the predominance of rhyolite among Yellowstone eruptive products, the reservoir is commonly perceived as rhyolitic. The presence of basalt beneath Yellowstone is suggested by the very large $\mathrm{CO}_{2}$ and $\mathrm{S}$ degassing rates (Werner and Brantley, 2003; Lowenstern and Hurwitz, 2008), yet there is no evidence for a deep mafic magma reservoir clearly separated from the imaged reservoir, in part because of the inability of current seismic tomography techniques to detect deeper structures (Husen et al., 2004; Stachnik et al., 2008; Smith et al., 2009). Thus, Smith et al. (2009) have proposed that the shallow crustal magma reservoir consists of a combination of basaltic dykes, sills, and magma chambers and melting zones where silicic magma is generated. Our geobarometry data on Central Plateau Member quartz crystals (see Table DR1 [footnote 1]) suggest depths of crystallization of $8-10 \mathrm{~km}$, which coincide with the imaged magma reservoir.

\section{FUTURE VOLCANISM AND HAZARDS}

\section{Southwestern and Central Caldera}

As outlined in the previous sections, evidence from crystal textures suggests rapid ascent of the Central Plateau Member magmas. Most of the recent eruptions (174-70 ka) were largevolume lava flows, also known as Snake River-type lavas (Branney et al., 2008). Their associated hazards remain largely unknown and their mechanisms of emplacement, including extrusion rates, are not well quantified (Branney et al., 2008). The amount of degassing associated with such eruptions is also unknown; degassing may have begun long before eruption while magma was still accumulating, suggesting the possibility of prolonged pre-eruptive degassing crises. Four pyroclastic units, the tuffs of Sulphur Creek (473 ka, $\left.\sim 10-50 \mathrm{~km}^{3}\right)$, Uncle Tom's Trail ( 480 ka, $\left.<1 \mathrm{~km}^{3}\right)$, Bluff Point (173 ka, $\left.50 \mathrm{~km}^{3}\right)$, and Cold Mountain Creek $\left(143 \mathrm{ka}, 10 \mathrm{~km}^{3}\right)$ are documented among the Upper Basin and Central Plateau members (Christiansen, 2001; Christiansen et al., 2007; Pritchard and Larson, 2012). The Tuff of Bluff Point was associated with the formation of the $6 \times 8 \mathrm{~km}$ West Thumb caldera of Yellowstone Lake (Christiansen, 2001) (Fig. 1). There is no clear geochemical difference between the pyroclastic tuffs and coeval lavas (Christiansen, 2001; Girard and Stix, 2009, 2010); hence, the factors causing these eruptions to be explosive rather than effusive are not known. Thus, the possibility of future intracaldera pyroclastic eruptions should not be ruled out. Should an eruption occur, the abundance of lakes, snow, groundwater, and hydrothermal areas within the caldera increases the likelihood of phreatomagmatic volcanism. The faults along which the Central Plateau eruptive vents are located remain tectonically active and would likely act as pathways for magma ascent, should eruptible magma be generated at depth.

\section{Northeastern Caldera}

In contrast with the southwestern and central regions of the caldera, where hundreds of cubic kilometers of magma have been erupted, no volcanism has occurred in the northeastern caldera since $480 \mathrm{ka}$ (Christiansen, 2001; Christiansen et al., 2007) (Fig. 3). 
Nevertheless, this region is undergoing significant ground deformation, including rapid uplift from 2004 to 2006, interpreted to reflect the injection of a sill at $\sim 10 \mathrm{~km}$ depth within the magma reservoir (Wicks et al., 2006; Chang et al., 2007, 2010; Smith et al., 2009) (Fig. 1). Some of the most active hydrothermal basins are located in this area, including the Mud Volcano area and the floor of Yellowstone Lake (Morgan et al., 2007, 2009). The largest documented hydrothermal explosion in Yellowstone, the Mary Bay crater, also formed in this area (Christiansen et al., 2007; Morgan et al., 2009). Numerous tectonic earthquakes are observed across this region; they are mainly distributed along a NNW-trending lineament that (1) cuts through the Sour Creek resurgent dome and Yellowstone Lake; (2) lies parallel to the Central Plateau eruptive vent lineaments; and (3) is aligned with an active extra-caldera fault, the Upper Yellowstone fault (Pierce and Morgan, 1992; Farrell et al., 2009) (Fig. 1). The presence of intracaldera faults such as the Yellowstone Lake fault (Fig. 1) may favor rapid eruption of newly generated magma. Thus, resumption of volcanism in the northeastern caldera, with eruptions and hazards similar to those of the Central Plateau Member, is a reasonable scenario.

\section{SUMMARY AND CONCLUSIONS}

1. In all investigated lavas, quartz crystals define two populations: unzoned crystals and zoned crystals with bright cores and dark rims when observed by cathodoluminescence. Bright cores and dark rims correlate with high Ti and low Ti concentrations, respectively, while the unzoned crystals have Ti concentrations similar to those of the zoned crystal rims. As lavas become younger, zoned quartz cores, zoned quartz rims, and unzoned crystals all exhibit progressively lower $\mathrm{Ti}$ concentrations. Geobarometry using $\mathrm{Ti}$ in quartz suggests crystallization at $\sim 8-10 \mathrm{~km}$ depth.

2. The generally rounded morphology of the quartz crystals and their abundant glass embayments suggest decompression, potentially preceded, or accompanied, by rapid heating. The lack of high-Ti overgrowths also suggests rapid ascent with no storage at shallow levels.

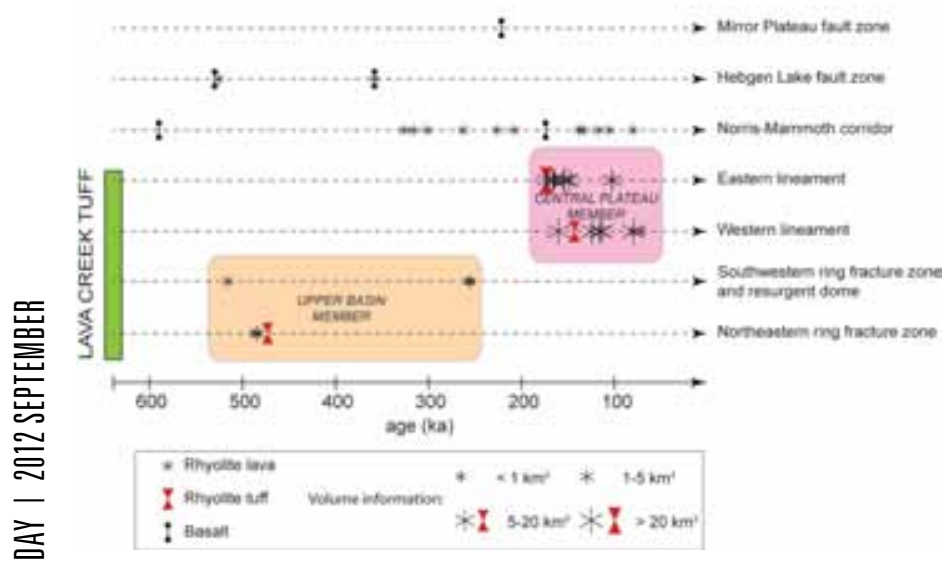

Figure 3. Distribution of Yellowstone eruptions by eruptive locations, age, style, and volumes, using data from Christiansen (2001) and Christiansen et al. (2007).

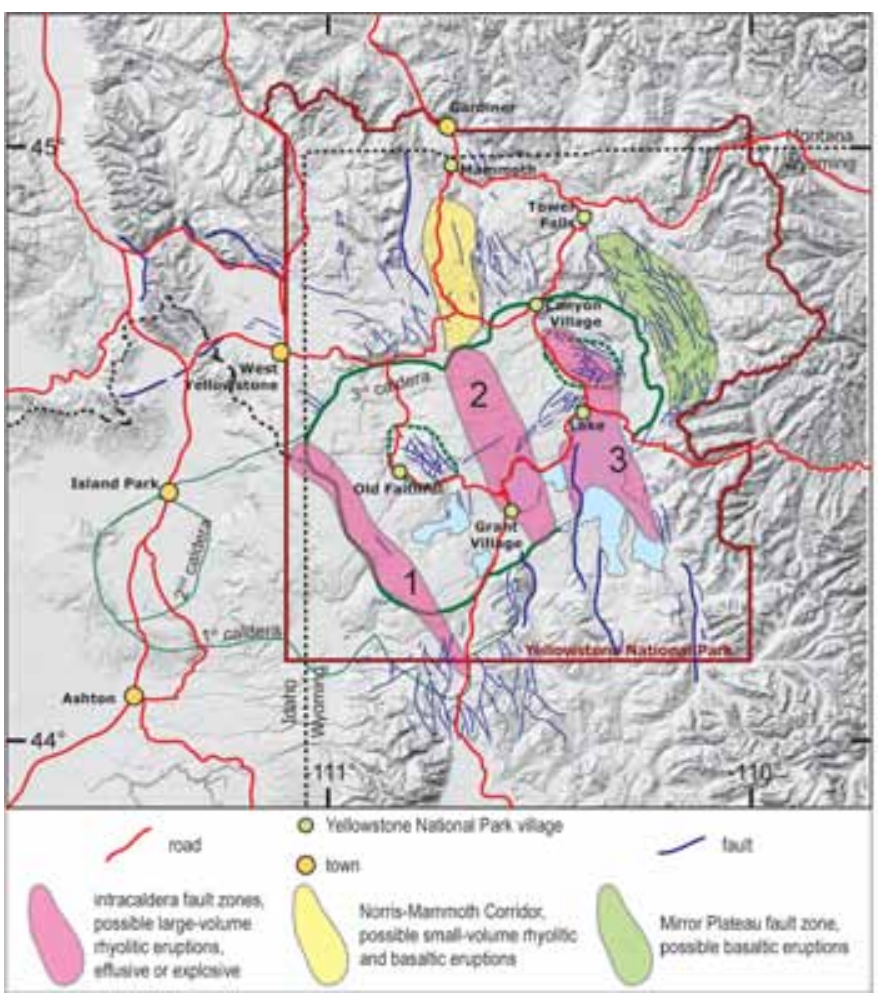

Figure 4. Map of the Yellowstone area showing our hypothesized foci of future volcanism in relation to the main National Park infrastructure, roads, and surrounding towns. The numbers 1,2 , and 3 refer to the three intracaldera fault-controlled lineaments as discussed in the text. See Christiansen et al. (2007) for a discussion of possible future extra-caldera volcanism in the NorrisMammoth corridor and Mirror Plateau fault zone.

3. A large crustal magma reservoir is interpreted to be present beneath Yellowstone caldera at between 16 and $6 \mathrm{~km}$ depth, but there is no indication that this reservoir, or parts of it, are currently in an eruptible state. However, rapid reheating and magma extraction events appear to have occurred episodically during times of Central Plateau magmatism.

4. If reactivation of the current reservoir were to occur, eruptions would most likely be focused along the two fault lines that localized all Central Plateau eruptions between 174 and $70 \mathrm{ka}$ and that continue to host intense caldera unrest (Fig. 4). A third parallel lineament across the northeastern caldera, while not hosting volcanism in the last half million years, focuses the most intense caldera unrest and is underlain by the magma reservoir (Figs. 1 and 4).

5. Eruptions could include large rhyolitic lava flows and/or pyroclastic eruptions, with generally unknown precursory signs and emplacement mechanisms, as well as phreatomagmatic eruptions due to the abundance of groundand surface water at Yellowstone.

\section{ACKNOWLEDGMENTS}

We thank Dr. Jake Lowenstern of the U.S. Geological Survey for comments on an early version of the manuscript, two anonymous reviewers who helped substantially improve this work, and Dr. Damian Nance for editorial handling. This work was supported by grants to John Stix from the Natural Sciences and Engineering Research Council of Canada. 


\section{REFERENCES CITED}

Bindeman, I.N., and Valley, J.W., 2001, Low- $\delta^{18} \mathrm{O}$ rhyolites from Yellowstone: Magmatic evolution based on analyses of zircons and individual phenocrysts: Journal of Petrology, v. 42, p. 1491-1517, doi: 10.1093/ petrology/42.8.1491.

Bindeman, I.N., Fu, B., Kita, N.T., and Valley, J.W., 2008, Origin and evolution of silicic magmatism at Yellowstone based on ion microprobe analysis of isotopically zoned zircons. Journal of Petrology, v. 49, p. 163-193, doi: 10. 1093/petrology/egm075.

Branney, M.J., Bonnichsen, B., Andrews, G.D.M., Ellis, B., Barry, T.L., and McCurry, M., 2008, "Snake River (SR)-type" volcanism at the Yellowstone hotspot track: Distinctive products from unusual, high-temperature silicic supereruptions: Bulletin of Volcanology, v. 70, p. 293-314, doi: 10.1007/s00445007-0140-7.

Campbell, M.E., Hanson, J.B., Minarik, W.G., and Stix, J., 2009, Thermal history of the Bandelier magmatic system: Evidence for magmatic injection and recharge at $1.61 \mathrm{Ma}$ as revealed by cathodoluminescence and titanium geothermometry: The Journal of Geology, v. 117, p. 469-485, doi: 10. $1086 / 604744$.

Castro, J.M., and Dingwell, D.B., 2009, Rapid ascent of rhyolitic magma at Chaitén volcano, Chile: Nature, v. 461, p. 780-784, doi: 10.1038/ nature 08458.

Chang, W.-L., Smith, R.B., Wicks, C., Farrell, J.M., and Puskas, C.M., 2007, Accelerated uplift and magmatic intrusion of the Yellowstone caldera, 2004 to 2006: Science, v. 318, p. 952-956, doi: 10.1126/science.1146842.

Chang, W.-L., Smith, R.B., Farrell, J., and Puskas, C.M., 2010, An extraordinary episode of Yellowstone caldera uplift, 2004-2010, from GPS and InSAR observation: Geophysical Research Letters, v. 37, L23302, doi: 10.1029/ 2010GL045451.

Christiansen, R.L., 2001, The Quaternary and Pliocene Yellowstone volcanic field of Wyoming, Idaho, and Montana: U.S. Geological Survey Professional Paper 729-G, $145 \mathrm{p}$.

Christiansen, R.L., Lowenstern, J.B., Smith, R.B., Heasler, H., Morgan, L.A., Nathenson, N., Mastin, L.G., Muffler, L.J.P., and Robinson, J.E., 2007, Preliminary assessment of volcanic and hydrothermal hazards in Yellowstone National Park and vicinity: U.S. Geological Survey Open-File Report 2007-1071, $94 \mathrm{p}$.

Chu, R., Helmberger, D.V., Sun, D., Jackson, J.M., and Zhu, L., 2010, Mushy magma beneath Yellowstone: Geophysical Research Letters, v. 37, L01306, doi: 10. 1029/2009GL041656.

DeNosaquo, K.R., Smith, R.B., and Lowry, A.R., 2009, Density and lithospheric strength models of the Yellowstone-Snake River plain volcanic system from gravity and heat flow data: Journal of Volcanology and Geothermal Research, v. 188, p. 108-127, doi: 10.1016/j.jvolgeores.2009.08.006.

Donaldson, C.H., and Henderson, C.M.B., 1988, A new interpretation of round embayments in quartz crystals: Mineralogical Magazine, v. 52, p. 27-33.

Doser, D.I., 1985, Source parameters and faulting process of the 1959 Hebgen Lake, Montana, earthquake sequence: Journal of Geophysical Research, v. 90, p. $4537-4556$.

Farrell, J., Husen, S., and Smith, R.B., 2009, Earthquake swarm and $b$-value characterization of the Yellowstone volcano-tectonic system: Journal of Volcanology and Geothermal Research, v. 188, p. 260-276, doi: 10.1016/j. jvolgeores.2009.08.008.

Girard, G., and Stix, J., 2009. Magma recharge and crystal mush rejuvenation at the origin of early post-collapse Upper Basin Member rhyolites, Yellowstone caldera, Wyoming: Journal of Petrology, v. 50, p. 2095-2125, doi: 10.1093/petrology/egp070.

Girard, G., and Stix, J., 2010, Rapid extraction of discrete magma batches from a large differentiating magma chamber: the Central Plateau Member rhyolites, Yellowstone Caldera, Wyoming: Contributions to Mineralogy and Petrology, v. 160, p. 441-465, doi: 10.1007/s00410-009-0487-1.

Hampel, A., Hetzel, R., and Densmore, A.L., 2007, Postglacial slip-rate increase on the Teton normal fault, northern Basin and Range Province, caused by melting of the Yellowstone ice cap and deglaciation of the Teton range?: Geology, v. 35, p. 1107-1110, doi: 10.1130/G24093A.1.

Hildreth, W., Christiansen, R.L., and O'Neil, J.R., 1984, Catastrophic isotopic modification of rhyolite magma at times of caldera subsidence,
Yellowstone Plateau Volcanic Field: Journal of Geophysical Research, v. 89, p. 8339-8369.

Hildreth, W., Halliday, A.N., and Christiansen, R.L., 1991, Isotopic and chemical evidence concerning the genesis and contamination of the basaltic and rhyolitic magmas beneath the Yellowstone Plateau Volcanic Field: Journal of Petrology, v. 32, p. 63-138.

Huang, R, and Audétat, A., 2012, The titanium-in-quartz (TitaniQ) geobarometer: a critical examination and recalibration: Geochimica and Cosmochimica Acta, v. 84, p. 75-89, doi: 10.1016/j.gca.2012.01.009.

Husen, S., Smith, R.B., and Waite, G.P., 2004, Evidence for gas and magmatic source beneath the Yellowstone volcanic field from seismic tomographic imaging: Journal of Geophysical Research, v. 131, p. 397-410.

Lanphere, M.A., Champion, D.E., Christiansen, R.L., Izett, G.A., and Obradovich, J.D., 2002, Revised ages for tuffs of the Yellowstone Plateau volcanic field; assignment of the Huckleberry Ridge Tuff to a new geomagnetic polarity event: GSA Bulletin, v. 114, p. 559-568.

Lowenstern, J.B., and Hurwitz, S., 2008, Monitoring a supervolcano in response: heat and volatile flux at the Yellowstone caldera: Elements v. 4, p. 35-40, doi: 10.113/gselements.4.1.35.

Lowenstern, J.B., Smith, R.B., and Hill, D.P., 2006, Monitoring super-volcanoes: geophysical and geochemical signals at Yellowstone and other large caldera systems: Philosophical Transactions of the Royal Society of London, ser. A, v. 364, p. 2055-2072, doi: 10.1098/rsta.2006.1813.

Marsh, B.D., 1981, On the crystallinity, probability of occurrence, and rheology of lava and magma: Contributions to Mineralogy and Petrology, v. 78, p. 85-98, doi: 10.1007/BF00371146.

Matthews, N.E., Pyle, D.M., Smith, V.C., Wilson, C.J.N., Huber, C., and van Hinsberg, V., 2012, Quartz zoning and the pre-eruptive evolution of the 340-ka Whakamaru magma systems, New Zealand: Contributions to Mineralogy and Petrology, v. 163, p. 87-107, doi: 10.1007/s00410-0110660-1.

Morgan, L.A., Shanks, W.C., III, Pierce, K.L., Lovalvo, D.A., Lee, G.K., Webring, M.W., Stephenson, W.J., Johnson, S.Y., Harlan, S.S., Schulze, B., and Finn, C.A., 2007, The floor of Yellowstone Lake is anything but quiet-New discoveries from high-resolution sonar imaging, seismic-reflection profiles, and submersible studies, in Morgan, L.A., ed., Integrated geoscience studies in the Greater Yellowstone Area-Volcanic, tectonic, and hydrothermal processes in the Yellowstone geoecosystem: U.S. Geological Survey Professional Paper 1717, p. 91-126.

Morgan, L.A., Shanks, W.C., III, and Pierce, K.L., 2009, Hydrothermal processes above the Yellowstone magma chamber: Large hydrothermal systems and large hydrothermal explosions: Geological Society of America Special Paper 459, $95 \mathrm{p}$.

Pierce, K.L., and Morgan, L.A., 1992, The track of the Yellowstone hotspot: Volcanism, uplift and faulting, in Link, P.K., Kuntz, M.A., and Platt, L.B., eds., Regional geology of Eastern Idaho and Western Wyoming: Geological Society of America Memoir 179, p. 1-53.

Pritchard, C.J., and Larson, P.B., 2012, Genesis of the post-caldera eastern Upper Basin Member rhyolites, Yellowstone, WY: From volcanic stratigraphy, geochemistry, and radiogenic isotope modeling: Contributions to Mineralogy and Petrology, doi: 10.1007/s00410-012-0733-9.

Puskas, C.M., Smith, R.B., Meertens, C.M., and Chang, W.L., 2007, Crustal deformation of the Yellowstone-Snake River Plain volcano-tectonic system: Journal of Geophysical Research, v. 112, B0341, doi: 10.1029/ 2006JB004325.

Shane, P., Smith, V.C., and Nairn, I.A., 2008, Millennial timescale resolution of rhyolite magma recharge at Tarawera volcano: Insights from quartz chemistry and melt inclusions: Contributions to Mineralogy and Petrology, v. 156, p. 397-411, doi: 10.1007/s00410-008-0292-2.

Smith, R.B., Jordan, M., Steinberger, B., Puskas, C.M., Farrell, J., Waite, G.P., Husen, S., Chang, W.-L., and O'Connell, R., 2009, Geodynamics of the Yellowstone hotspot and mantle plume: Seismic and GPS imaging, kinematics, and mantle flow: Journal of Volcanology and Geothermal Research, v. 188, p. 26-56, doi: 10.1016/j.jvolgeores.2009.08.020.

Sparks, R.S.J., Self, S., Grattan, J.P., Oppenheimer, C., Pyle, D.M., and Rymer, H., 2005, Super-eruptions: Global effects and future threats: London, UK, Report of a Geological Society of London working group, $24 \mathrm{p}$. 
Stachnik, J.C., Dueker, K., Schutt, D.L., and Yuan, H., 2008, Imaging Yellowstone plume-lithosphere interactions from inversion of ballistic and diffusive Rayleigh wave dispersion and crustal thickness data: Geochemistry Geophysics Geosystems, v. 9, Q06004, doi: 10.1029/2008GC001992.

Streck, M.J., 2008, Mineral textures and zoning as evidence for open system processes, in Putirka, K.D., and Tepley, F.J., III, eds., Mineral, inclusions, and volcanic processes: Reviews in Mineralogy and Geochemistry, v. 69, p. 595-622, doi: 10.2138/rmg.2008.69.15.

Taira, T., Smith, R.B., and Chang, W.-L., 2010, Seismic evidence for dilatational source deformations accompanying the 2004-2008 Yellowstone accelerated uplift episode: Journal of Geophysical Research, v. 115, B02301, doi: 10. 1029/2008JB006281.

Thomas, J.B., Watson, E.B., Spear, F.S., Shemella, P.T., Nayak, S.K., and Lanzirotti, A., 2010, TitaniQ under pressure: The effect of pressure and temperature on the solubility of Ti in quartz: Contributions to Mineralogy and Petrology, v. 160, p. 743-759, doi: 10.1007/s00410-010-0505-3.

Vazquez, J.A., Kyriazis, S.F., Reid, M.R., Sehler, R.C., and Ramos, F.C., 2009, Thermochemical evolution of young rhyolites at Yellowstone: Evidence for a cooling but periodically replenished postcaldera magma reservoir: Journal of Volcanology and Geothermal Research, v. 188, p. 186-196, doi: 10.1016/j.jvolgeores.2008.11.030.

Waite, G.P., and Smith, R.B., 2002, Seismic evidence for fluid migration accompanying subsidence of the Yellowstone caldera: Journal of Geophysical Research, v. 107, B2177, doi: 10.1029/2001JB000586.
Wark, D.A., and Watson, E.B., 2006, TitaniQ: a titanium-in-quartz geothermometer: Contributions to Mineralogy and Petrology, v. 152, p. 743-754, doi: 10.1007/ s00410-006-0132-1.

Wark, D.A., Hildreth, W., Spear, F.S., Cherniak, D.J., and Watson, E.B., 2007, Pre-eruption recharge of the Bishop magma system: Geology, v. 35, p. 235-238, doi: 10.1130/G23316A.1.

Watts, K.E., Bindeman, I.N., and Schmitt, A.K., 2012, Crystal scale anatomy of a dying supervolcano: an isotope and geochronology study of individual phenocrysts from voluminous rhyolites of the Yellowstone caldera: Contributions to Mineralogy and Petrology, v. 164, p. 45-67, doi: 10.1007/s00410-012-0724-x.

Werner, C., and Brantley, S., 2003, $\mathrm{CO}_{2}$ emissions from the Yellowstone volcanic system: Geochemistry Geophysics Geosystems, v. 4, 1061, doi: 10.1029/ $2002 \mathrm{GC} 000473$.

Wicks, C.W., Thatcher, W., Dzurisin, D., and Svarc, J., 2006, Uplift, thermal unrest and magma intrusion at Yellowstone caldera: Nature, v. 440, p. 72-75, doi: 10.1038 /nature04507.

Wiebe, R.A., Wark, D.A., and Hawkins, D.P., 2007, Insights from quartz cathodoluminescence zoning into crystallization of the Vinalhaven granite, coastal Maine: Contributions to Mineralogy and Petrology, v. 154, p. 439453, doi: 10:1007/s00410-007-0202-z.

Manuscript received 12 Nov. 2011; accepted 16 May 2012.

\section{G MALÂ \\ Professional Explorer (ProEx ${ }^{\mathrm{TM}}$ ) Ground Penetrating Radar There Are No Limits}

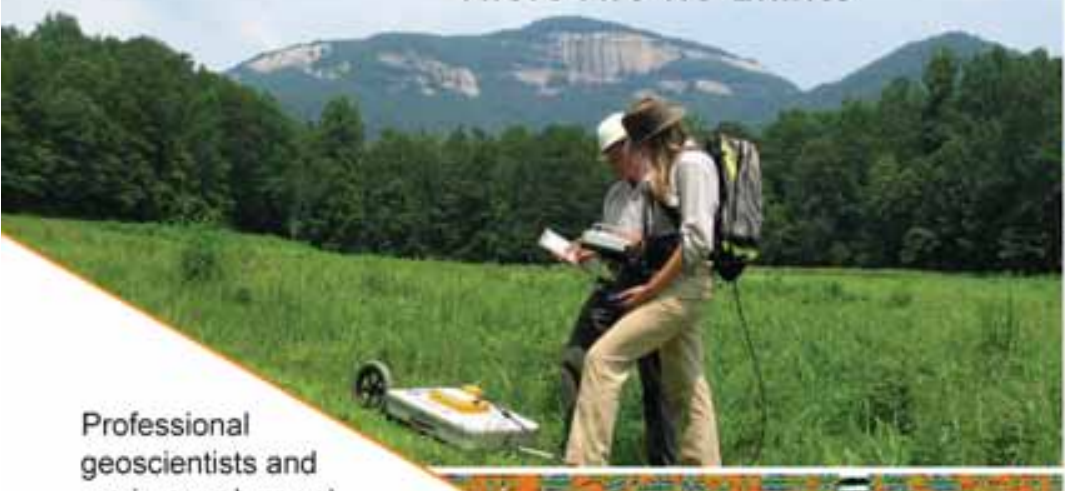
engineers demand unlimited application capabilities from their GPR systems.

From subsurface geologic mapping to highway speed roadway investigations the ProEx delivers.

Head Office - Mala GeoScience AB

Skolgatan 11, SE-930 70

Phone - +46953 34550 Fax - +4695334567

E-mail: sales@malags.com
USA Office - Mala GeoScience USA, Inc. PO Box 80430 Charleston, SC 29416

Phone - 843-852-5021 Fax - 843-769-7392

E-mail: sales.usa@malags.com

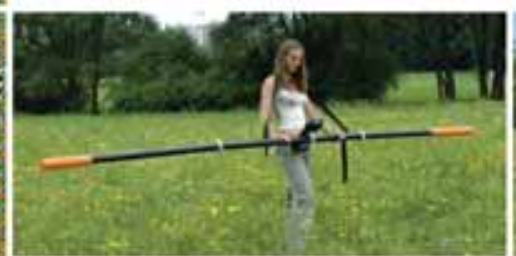

Essential Exploration Tools

- Electrical Resistivity Imaging Systems EM Conductivity Meters Magnetic Susceptibility Meters - Gamma-Ray Spectrometers

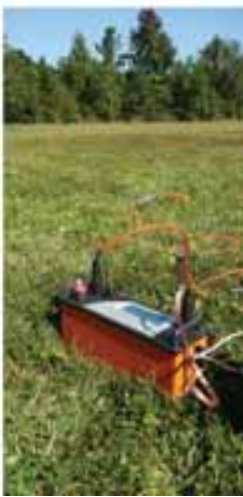

